\title{
FORMULATION AND EVALUATION OF FAST DISSOLVING TABLET OF KETOROLAC TROMETHAMINE
}

\section{SANGEETHA G, MAHESH PG*, CHANTHINI K, LOKESH M, AMEEN S}

Department of Pharmaceutics, School of Pharmaceutical Sciences, Vels Institute of Science Technology and Advanced Studies, Pallavaram, Chennai - 600 117, Tamil Nadu, India. Email: pgmahesh83@gmail.com

Received: 10 October 2018, Revised and Accepted: 11 December 2018

\section{ABSTRACT}

Aim and Objective: Ketorolac tromethamine is used for treatment of infections including infection of joints and bones, gastroenteritis, malignant Otis externa, respiratory tract infections, cellulites, urinary tract infections, anthrax and it also used in treatment of community acquired pneumonia. Difficulty in swallowing is a common problem of all age groups, especially the elderly and pediatrics, because of physiological changes associated with these groups.

Methods: Pre formulation testing is an investigation of physical and chemical properties of drug substances alone and when combined with pharmaceutical excipients. It is the first step in the rational development of dosage form.

Results: The present study was undertaken to formulate Ketorolac tromethamine oral dispersible tablet with three polymers namely sodium starch glycolate, cros carmellose sodium and in combination of three super disintegrants and by dry granulation technique. Before compression of the garnules physical characters such as bulk density, tappd density, angle of repose, compressibility index and hausner ratio was determined and tabulated. Then the granules were compressed into tablets and then evaluated.

Conclusion: It has been observed from all formulations of pre compression and post compression studies were given with in the limits of values. The in vitro dissolution data, F1 (combination of super disintegrant) formulation was found that the drug release is best and cumulative \% of drug release was $90.88 \%$ respectively, when compared to other formulation.

Keywords: Ketorolac tromethamine, Sodium starch glycolate, Cros carmellose

(C) 2018 The Authors. Published by Innovare Academic Sciences Pvt Ltd. This is an open access article under the CC BY license (http://creativecommons. org/licenses/by/4. 0/) DOI: http://dx.doi.org/10.22159/ajpcr.2018.v11s4.31728

\section{INTRODUCTION}

Recent developments in technology have presented viable alternatives for the patients who may have difficulty in swallowing tablets or liquids. Traditional tablets and capsules administered with an 8-oz glass of water [1] may be inconvenient or impractical for some patients. For example, a very elderly patient may not be able to swallow a daily dose [2] of tablets. [3] Some drugs are absorbed from mouth, pharynx and esophagus as saliva passes down to stomach [4] An inability or willingness to swallow solid oral dosage forms such as tablets and poor taste of medicine are some of the important reasons for consumer dissatisfaction(5) A schizophrenic patient in the institution setting can hide a conventional tablet under his/her tongue to avoid daily dose of atypical anti psychotic(6) The amount of drug that is subjected to first pass metabolism is reduced as compared to standard tablets(7) Fast dissolving tablet is a solid dosage form that disintegrants and dissolves in he mouth(8) The fast dissolving tablet that can be placed in the mouth where it disperses rapidly before swallowing(9)

\section{METHODS}

Pre-formulation studies

Pre formulation testing is an investigation of physical and chemical properties of drug substances alone and when combined with pharmaceutical excipients. It is the first step in the rational development of dosage form.

\section{Standard curve of ketorolac tromethamine}

Sodium hydroxide solution, $0.2 \mathrm{~m}$

$8 \mathrm{~g}$ of sodium hydroxide was dissolved in $1000 \mathrm{ml}$ distilled water, and it gives $0.2 \mathrm{~m}$ solution.

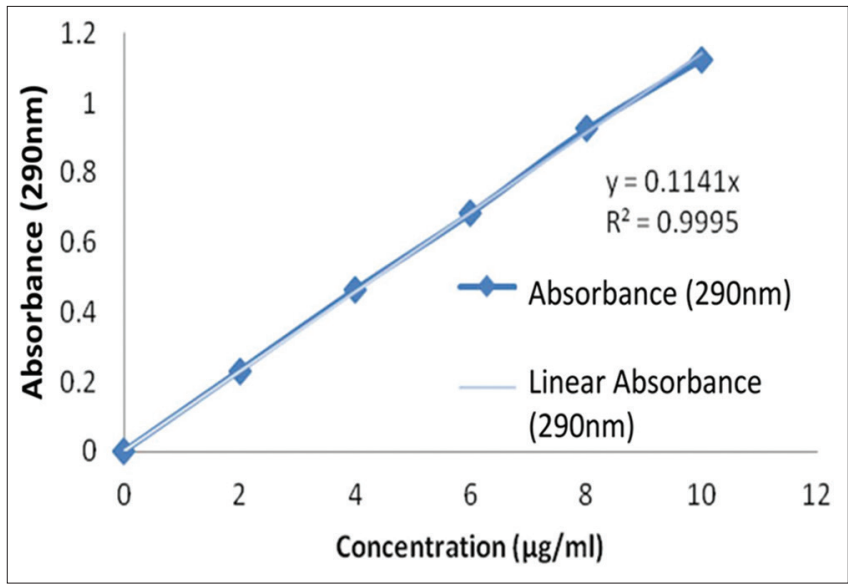

Fig. 1: Standard curve of ketorolac tromethamine in phosphate buffer (pH 6.8)

Table 1: Standard curve of ketorolac tromethamine in phosphate buffer (pH 6.8)

\begin{tabular}{lll}
\hline S. No. & Concentration $(\boldsymbol{\mu g} / \mathbf{m l})$ & Absorbance $(\mathbf{2 9 0} \mathbf{~ n m})$ \\
\hline 1. & 0 & 0.00 \\
2. & 2 & 0.232 \\
3. & 4 & 0.465 \\
4. & 6 & 0.684 \\
5. & 8 & 0.926 \\
6. & 10 & 1.126 \\
\hline
\end{tabular}




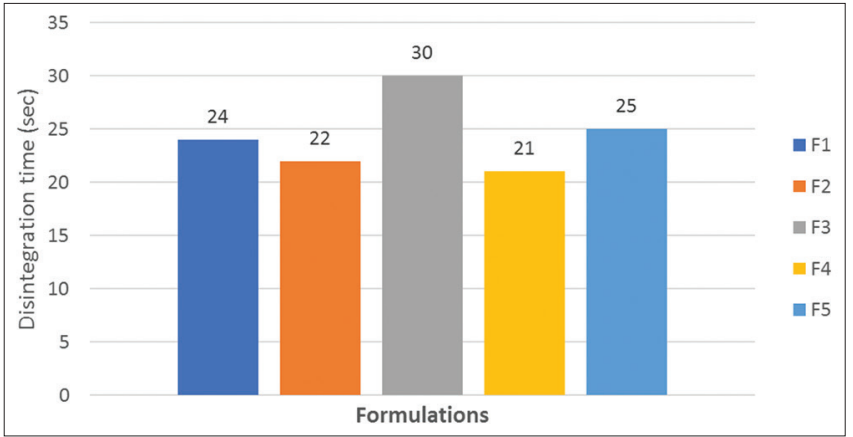

Fig. 2: Disintegration time

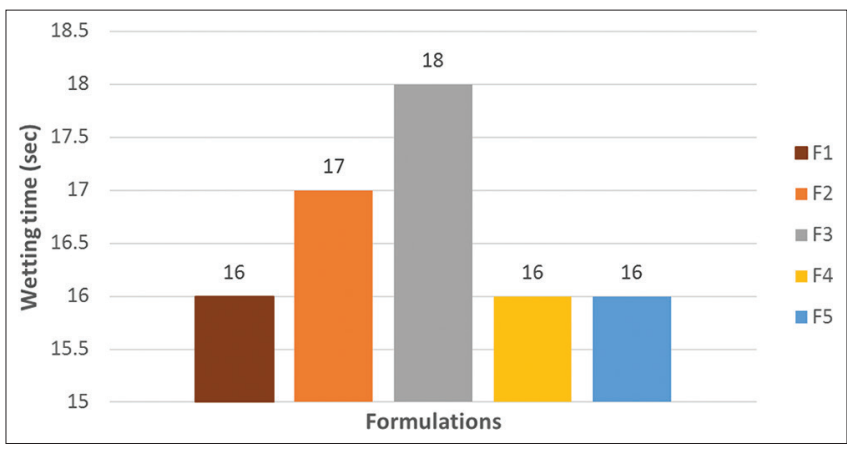

Fig. 3: Wetting time
Standard curve of ketorolac tromethamine

Potassium dihydrogen phosphate solution

$0.2 \mathrm{M} 27.218 \mathrm{gm}$ of potassium dihydrogen phosphate was dissolved in $1000 \mathrm{ml}$ distilled water in a volumetric flask.

\section{Sodium hydroxide solution, $0.2 \mathrm{M}$}

$8 \mathrm{gm}$ of sodium hydroxide was dissolved in $1000 \mathrm{ml}$ distilled water and gives $0.2 \mathrm{M}$ solution

\section{Preparation of pH6.8 buffer}

Place $50.0 \mathrm{ml}$ of $0.2 \mathrm{M}$ potassium di hydrogen phosphate in a $200 \mathrm{ml}$ volumetric flask add $22.4 \mathrm{ml}$ sodium hydroxide and then make up with water upto volume.

This is standard curve of Ketorolac tromethamine phosphate buffer with absorbance 290nM and linear absorbance 290nM. Its showing in Fig 1.

The disintegration time (D.T) of all formulations is shown in the Fig 2.

$100 \mathrm{mg}$ of pure drug of ketorolac tromethamine was dissolved in $10 \mathrm{ml}$ volumetric flask and shaked with $5 \mathrm{ml}$ methanol. for the above solution add remaining amount was make up with $6.8 \mathrm{pH}$ Phosphate buffer.This solution contains $1000 \mu \mathrm{g} / \mathrm{ml}$ of ketorolac tromethamine stock solution. Take $10 \mathrm{ml}$ from above solution in $100 \mathrm{ml}$ volumetric flask and make up with $6.8 \mathrm{pH}$ phosphate buffer. This solution contains $100 \mu \mathrm{g} / \mathrm{ml}$ of drug. From above solution take $1 \mathrm{ml}$ in $10 \mathrm{ml}$ volumetric flask and make up with $6.8 \mathrm{pH}$ phosphate buffer. From this solution pipette out $0.2 \mathrm{ml}$ in $10 \mathrm{ml}$ volumetric flask add buffer. This gives $0.2 \mu \mathrm{g} / \mathrm{ml}$ solution. Similarly

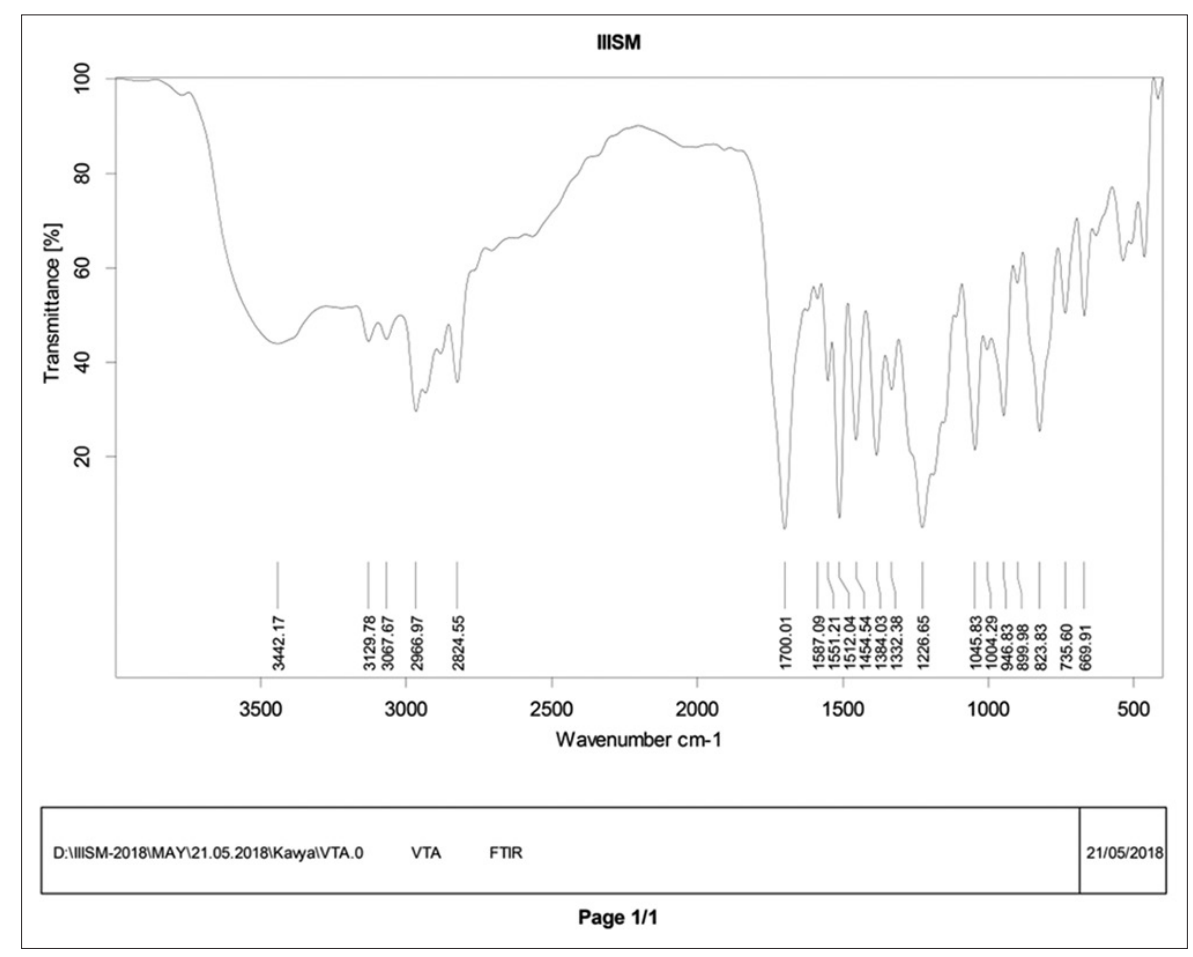

Fig.4: FTIR spectrum of ketorolac tromethamine.

Table 2: Different formulation of ketorolac tromethamine oral dispersible tablets

\begin{tabular}{|c|c|c|c|c|c|c|c|c|}
\hline S. No. & Formulation code & Drug & SSG & CCS & Mannitol & Sodium saccharin & Magnesium stearate & Mint flavor \\
\hline 1. & $\mathrm{~F} 1$ & 10 & 5 & - & 78 & 5 & 2 & q. $s$ \\
\hline 2. & $\mathrm{~F} 2$ & 10 & 10 & - & 73 & 5 & 2 & q. $s$ \\
\hline 3. & F3 & 10 & - & 5 & 78 & 5 & 2 & q. $s$ \\
\hline 4. & $\mathrm{~F} 4$ & 10 & - & 10 & 73 & 5 & 2 & q. $s$ \\
\hline 5. & F5 & 10 & 5 & 5 & 73 & 5 & 2 & q. $s$ \\
\hline
\end{tabular}

CCS: Croscarmellose sodium, SSG: Sodium starch glycolate 


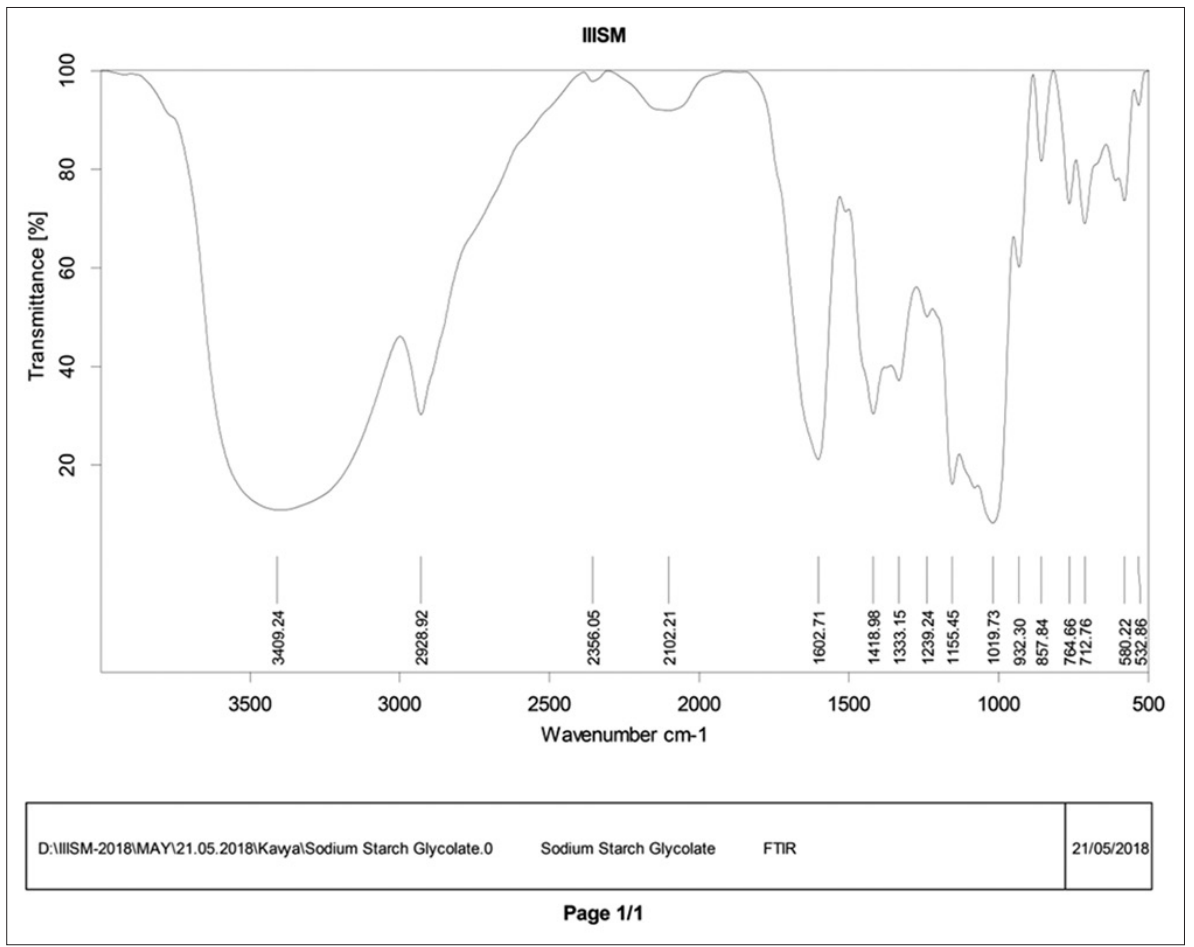

Fig. 5: FTIR Spectrum of Sodium starch glycolate

Table 3: Pre-compression studies of powder blend

\begin{tabular}{|c|c|c|c|c|c|c|}
\hline S. No. & Formulations & $\begin{array}{l}\text { Hardness } \\
\text { test }(\mathrm{kg} / \mathrm{cm})\end{array}$ & $\begin{array}{l}\text { Thickness } \\
\text { test }(\mathbf{c m})\end{array}$ & $\begin{array}{l}\text { Friability } \\
\text { test (\%) }\end{array}$ & $\begin{array}{l}\% \text { of weight } \\
\text { variation test }\end{array}$ & $\begin{array}{l}\text { Estimation of } \\
\text { drug content }\end{array}$ \\
\hline 1. & F1 & 2.35 & 0.35 & 0.154 & 99.5 & 98.22 \\
\hline 2. & $\mathrm{~F} 2$ & 2.44 & 0.35 & 0.218 & 99.7 & 96.39 \\
\hline 3. & F3 & 3.52 & 0.35 & 0.256 & 99.8 & 97.64 \\
\hline 4. & $\mathrm{~F} 4$ & 2.82 & 0.35 & 0.277 & 99.7 & 97.57 \\
\hline 5. & F5 & 2.75 & 0.35 & 0.234 & 99.7 & 95.48 \\
\hline
\end{tabular}

Table 4: Pre compression studies of Powder blend

\begin{tabular}{|c|c|c|c|c|c|c|}
\hline S. No. & Formulations & $\begin{array}{l}\text { Bulk density (g/ } \\
\mathrm{cm}^{3} \text { ) }\end{array}$ & $\begin{array}{l}\text { Tapped density } \\
\left(\mathrm{g} / \mathrm{cm}^{3}\right)\end{array}$ & $\begin{array}{l}\text { Angle of } \\
\text { repose }(\theta)\end{array}$ & $\begin{array}{l}\text { Carr's } \\
\text { index }(\%)\end{array}$ & $\begin{array}{l}\text { Hausner's } \\
\text { ratio }\end{array}$ \\
\hline 1. & $\mathrm{~F} 1$ & 0.384 & 0.385 & 31.26 & 10.73 & 1.322 \\
\hline 2. & $\mathrm{~F} 2$ & 0.356 & 0.362 & 35.15 & 6.58 & 1.175 \\
\hline 3. & F3 & 0.358 & 0.372 & 32.82 & 9.29 & 1.203 \\
\hline 4. & F4 & 0.382 & 0.323 & 32.38 & 6.10 & 1.167 \\
\hline 5. & F5 & 0.343 & 0.358 & 34.07 & 9.21 & 1.005 \\
\hline
\end{tabular}

preparing $0.4 \mathrm{ml}, 0.6 \mathrm{ml}, 0.8 \mathrm{ml}$ and $1 \mathrm{ml}$ of solution in $10 \mathrm{ml}$ volumetric flasks. Resulting gives $2 \mu \mathrm{g} / \mathrm{ml}, 4 \mu \mathrm{g} / \mathrm{ml}, 6 \mu \mathrm{g} / \mathrm{ml}$,

$8 \mu \mathrm{g} / \mathrm{ml}$ and $10 \mu \mathrm{g} / \mathrm{ml}$ solutions. The concentrated solution scanned in UV-Visible Spectrophotometer meter with absorption maimum is 290nm shown in Table 1.

In this method, all the powder excipients are mixed thoroughly in a polyethylene bag. After proper mixing the powder was punched into tablets. The weight of the tablet was $400 \mathrm{mg}$ and dose of the drug is $150 \mathrm{mg}$. Each tablet weight-100mg shown in Table 2.

The compressed tablets were evaluated for physical properties and the results are tabulated for Hardness test, Thickness test, Friability test, \% of weight variation test and Estimation of drug content values showed in Table 3.

\section{Method of preparation}

Preparation of ketorolac tromethamine tablets

Direct compression technique

Each tablet wetting time (WT) - $100 \mathrm{mg}$.

Pre compression studies of powder blend

Angle of repose

$$
\theta=\operatorname{Tan}^{-1}(\mathrm{~h} / \mathrm{r})
$$

Where

$\theta=$ Angle of repose,

$\mathrm{h}=$ Height of the powder cone,

$\mathrm{r}=$ Radius of the powder cone. 


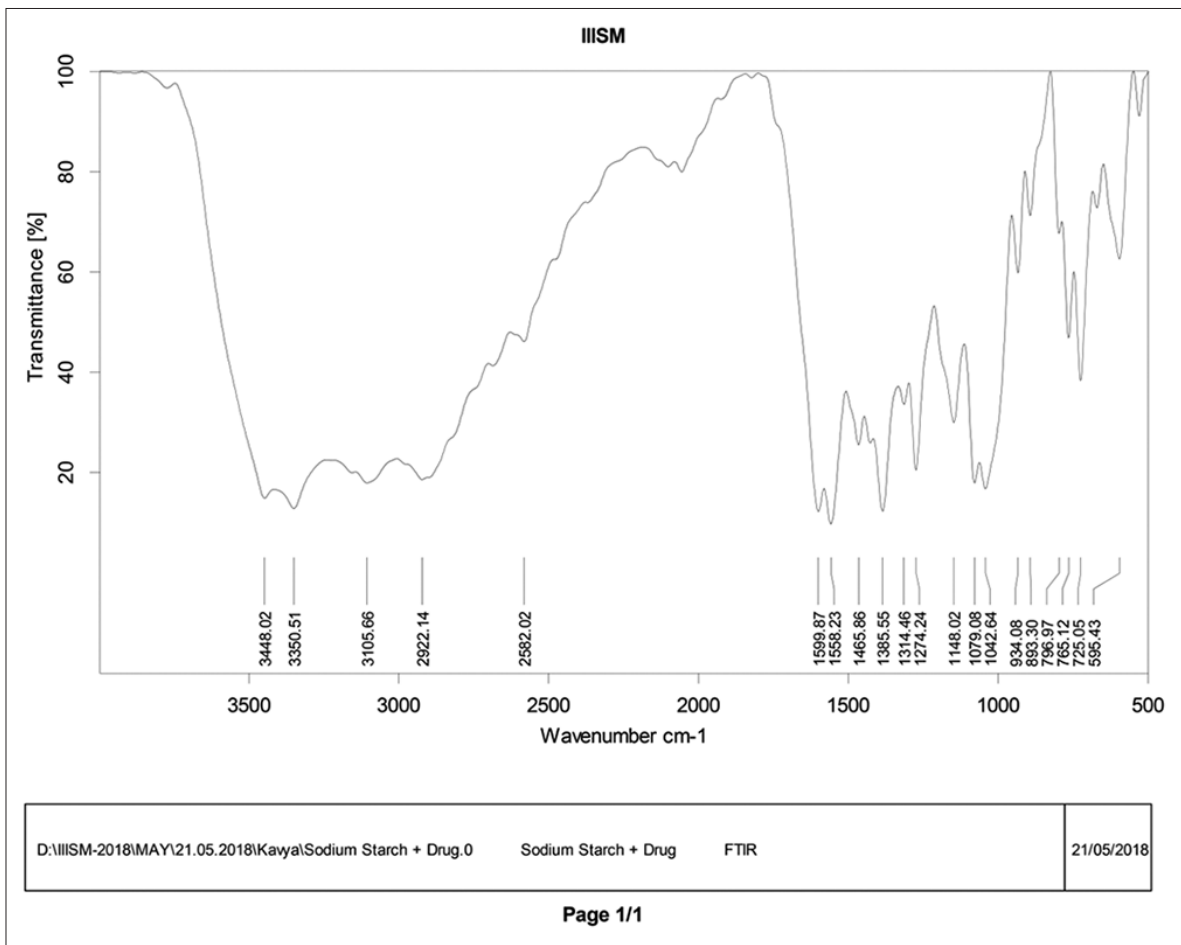

Fig. 6: FTIR Spectrum of ketorolac tromethamine and sodium starch glycolate

Table 5: Post-compression studies of ketorolac tromethamine oral dispersible tablets

\begin{tabular}{llll}
\hline S. No. & Formulations & Disintegration time (s) & WT (s) \\
\hline 1. & F1 & 24 & 16 \\
2. & F2 & 22 & 17 \\
3. & F3 & 30 & 18 \\
4. & F4 & 21 & 16 \\
5. & F5 & 25 & 16 \\
\hline
\end{tabular}

WT: Wetting time

Table 6: FTIR spectrum of ketorolac tromethamine.

\begin{tabular}{lll}
\hline S. No. & Wave number & Functional group \\
\hline 1. & 3442 & OH stretching carboxylic acid \\
2. & 3129 & =CH aromatic heterocyclic stretching \\
3. & 3067 & =CH aromatic stretching \\
4. & 2966 & alkyl stretching \\
5. & 1226 & C-N stretching \\
6. & 1454 & Alkyl CH2 bending \\
7. & 1384 & Alkyl CH2 bending \\
8. & 899 & CH- aromatic bending \\
9. & 1700 & C = O stretching \\
10. & 1384 & C-OH bending \\
\hline
\end{tabular}

FTIR: Fourier-transform infrared spectroscopy

Table 7: FTIR Spectrum of Sodium starch glycolate

\begin{tabular}{lcl}
\hline S. No. & Wave number & Functional group \\
\hline 1. & 3409 & OH stretching \\
2. & 2928 & alkyl CH stretching \\
3. & 1602 & COO anti-symmetry stretching \\
4. & 1239 & C-O-C stretching \\
\hline
\end{tabular}

FTIR: Fourier-transform infrared spectroscopy, SSG: Sodium starch glycolate

\section{RESULTS AND DISCUSSIONS}

Pre-formulation studies

The present study was undertaken to formulate Ketorolac tromethamine oral dispersible tablet with three polymers namely

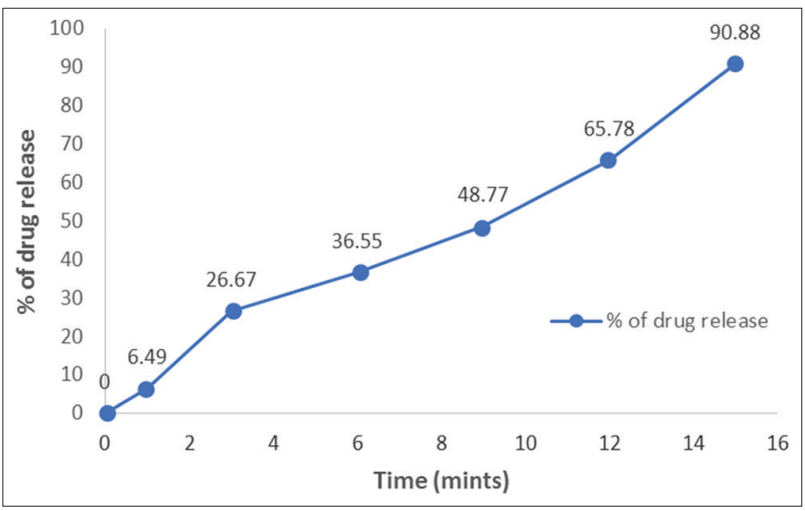

Fig. 7: Formulation-1 (F1)

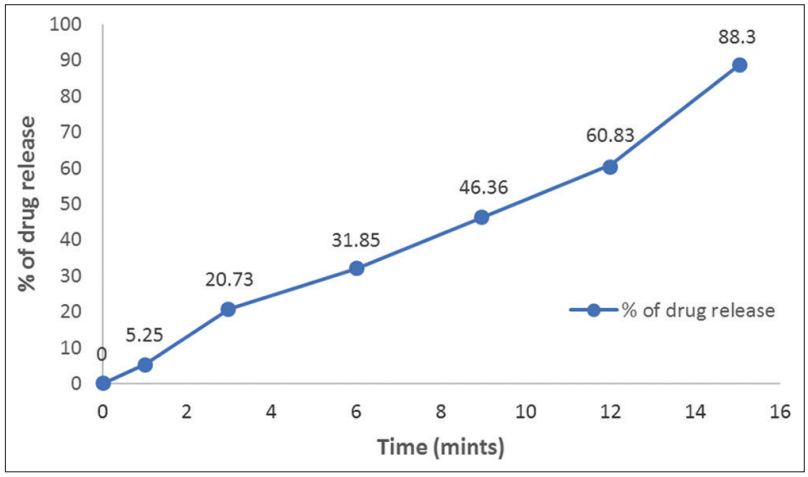

Fig. 8: Formulation-2 (F2)

sodium starch glycolate, cros carmellose sodium and in combination of three super disintegrants and by dry granulation technique. Before compression of the granules physical characters such as bulk density, tapped density, angle of repose, compressibility index and hausner ratio was determined and tabulated. Then the granules were compressed into tablets and then evaluated. 
Table 8:FTIR Spectrum of ketorolac tromethamine and sodium starch glycolate

\begin{tabular}{lll}
\hline S. No. & Wave number & Functional group \\
\hline 1. & 3350 & OH stretching \\
2. & 3105 & $=$ CH aromatic heterocyclic ring \\
3. & 2922 & alkyl CH stretching \\
\hline FTIR: & Fourier-transform infrared spectroscopy, SSG: Sodium starch glycolate
\end{tabular}

WT study

The WT of all formulations is shown in Table 5 and Fig. 3.

The disintegration time (D.T) of all formulations is shown in the Table 5.

The IR Spectral studies of pure ketorolac tromethamine were carried out to study the interaction between the drug and super disintegrants used. It showed that IR spectrum of pure drug ketorolac tromethamine

Table 9: Formulations-1 (F1)

\begin{tabular}{|c|c|c|c|c|c|}
\hline S. No. & Time (min) & Absorbance $(290 \mathrm{~nm})$ & Concentration $(\mu \mathrm{g} / \mathrm{ml})$ & Amount of drug release (in $900 \mathrm{ml}$ ) & $\%$ of drug release \\
\hline 1. & 0 & 0.000 & 0.000 & 0.000 & 0.000 \\
\hline 2. & 1 & 0.128 & 1.068 & 9.810 & 6.49 \\
\hline 3. & 3 & 0.498 & 4.354 & 39.85 & 26.67 \\
\hline 4. & 6 & 0.687 & 6.010 & 54.20 & 36.55 \\
\hline 5. & 9 & 0.922 & 8.056 & 72.66 & 48.77 \\
\hline 6. & 12 & 1.243 & 10.976 & 98.68 & 65.78 \\
\hline 7. & 15 & 1.724 & 15.184 & 136.01 & 90.88 \\
\hline
\end{tabular}

Table 10: Formulations-2 (F2)

\begin{tabular}{|c|c|c|c|c|c|}
\hline S. No. & Time (min) & Absorbance $(290 \mathrm{~nm})$ & Concentration $(\mu \mathrm{g} / \mathrm{ml})$ & Amount of drug release (in $900 \mathrm{ml}$ ) & $\%$ of drug release \\
\hline 1. & 0 & 0.000 & 0.000 & 0.000 & 0.000 \\
\hline 2. & 1 & 0.076 & 0.852 & 7.598 & 5.25 \\
\hline 3. & 3 & 0.382 & 3.478 & 30.84 & 20.73 \\
\hline 4. & 6 & 0.568 & 5.172 & 46.43 & 31.85 \\
\hline 5. & 9 & 0.878 & 7.73 & 69.89 & 46.36 \\
\hline 6. & 12 & 1.162 & 10.30 & 90.74 & 60.83 \\
\hline 7. & 15 & 1.654 & 14.88 & 132.89 & 88.30 \\
\hline
\end{tabular}

Table 11: Formulations-3 (F3)

\begin{tabular}{|c|c|c|c|c|c|}
\hline S. No. & Time (min) & Absorbance $(290 \mathrm{~nm})$ & Concentration $(\mu \mathrm{g} / \mathrm{ml})$ & Amount of drug release (in $900 \mathrm{ml}$ ) & $\%$ of drug release \\
\hline 1 & 0 & 0.000 & 0.000 & 0.000 & 0.000 \\
\hline 2 & 1 & 0.072 & 0.779 & 6.493 & 4.325 \\
\hline 3 & 3 & 0.384 & 3.182 & 28.53 & 19.35 \\
\hline 4 & 6 & 0.582 & 4.689 & 44.86 & 29.67 \\
\hline 5 & 9 & 0.863 & 7.472 & 67.54 & 44.99 \\
\hline 6 & 12 & 1.116 & 9.601 & 87.81 & 58.71 \\
\hline 7 & 15 & 1.593 & 13.98 & 124.7 & 83.81 \\
\hline
\end{tabular}

Table 12: Formulations-4 (F4)

\begin{tabular}{|c|c|c|c|c|c|}
\hline S. No. & Time (min) & Absorbance $(290 \mathrm{~nm})$ & Concentration $\mu \mathrm{g} / \mathrm{ml}$ ) & Amount of drug release (in $900 \mathrm{ml}$ ) & $\%$ of drug release \\
\hline 1. & 0 & 0.000 & 0.000 & 0.000 & 0.000 \\
\hline 2. & 1 & 0.108 & 0.947 & 8.526 & 5.684 \\
\hline 3. & 3 & 0.405 & 3.552 & 31.97 & 21.31 \\
\hline 4. & 6 & 0.612 & 5.368 & 48.31 & 32.21 \\
\hline 5. & 9 & 0.894 & 7.842 & 70.57 & 47.05 \\
\hline 6. & 12 & 1.168 & 10.24 & 92.21 & 61.47 \\
\hline 7. & 15 & 1.686 & 14.78 & 133.1 & 88.73 \\
\hline
\end{tabular}

Table 13: Formulations-5 (F5)

\begin{tabular}{|c|c|c|c|c|c|}
\hline S. No. & Time (min) & Absorbance (290 nm) & Concentration $(\mu \mathrm{g} / \mathrm{ml})$ & Amount of drug release (in $900 \mathrm{ml}$ ) & $\%$ of drug release \\
\hline 1. & 0 & 0.000 & 0.000 & 0.000 & 0.000 \\
\hline 2. & 1 & 0.108 & 0.947 & 8.526 & 5.684 \\
\hline 3. & 3 & 0.405 & 3.552 & 31.97 & 21.31 \\
\hline 4. & 6 & 0.612 & 5.368 & 48.31 & 32.21 \\
\hline 5. & 9 & 0.894 & 7.842 & 70.57 & 47.05 \\
\hline 6. & 12 & 1.168 & 10.24 & 92.21 & 61.47 \\
\hline 7. & 15 & 1.686 & 14.78 & 133.1 & 88.73 \\
\hline
\end{tabular}


Table 14: Comparative dissolution study of different formulations with various ratios of super disintegrants

\begin{tabular}{|c|c|c|c|c|c|c|}
\hline S. No. & Time (min) & $\%$ of drug release (F1) & $\%$ of drug release (F2) & $\%$ of drug release (F3) & $\%$ of drug release (F4) & $\%$ of drug release (F5) \\
\hline 1. & 0 & 0.000 & 0.000 & 0.000 & 0.000 & 0.000 \\
\hline 2. & 1 & 6.49 & 5.25 & 4.325 & 6.947 & 5.684 \\
\hline 3. & 3 & 26.67 & 20.73 & 19.35 & 27.42 & 21.31 \\
\hline 4. & 6 & 36.55 & 31.85 & 29.67 & 36.52 & 32.21 \\
\hline 5. & 9 & 48.77 & 46.36 & 44.99 & 49.57 & 47.05 \\
\hline 6. & 12 & 65.78 & 60.83 & 58.71 & 66.10 & 61.47 \\
\hline 7. & 15 & 90.88 & 88.30 & 83.81 & 92.78 & 88.73 \\
\hline
\end{tabular}

and super disintegrants were similar fundamental peaks and patterns. The results proved that there were no significant interactions between the drug and super disintegrants. The results are shown in Table 6 and Fig 4.

The IR Spectral studies of sodium starch glycolate were carried out to study the interaction between the drug and super disintegrants used. It showed that IR spectrum of pure drug ketorolac tromethamine and super disintegrants were similar fundamental peaks and patterns. The results proved that there were no significant interactions between the drug and super disintegrants. The results are shown in Table 7 and Fig 5.

The IR Spectral studies of pure ketorolac tromethamine, sodium starch glycolate were carried out to study the interaction between the drug and super dis integrants used. It showed that IR spectrum of pure drug ketorolac tromethamine and super disintegrants were similar fundamental peaks and patterns. The results proved that there were no significant interactions between the drug and super disintegrants. The results are shown in Table 8 and Fig 6.

The in vitro drug release profile of tablets from formulation 1 batch was carried in phosphate buffer ( $\mathrm{pH}$ 6.8) for $15 \mathrm{mts}$ by using paddle type of device. From the in vitro dissolution data, F1 formulation was found that that drug release and cumulative \% of drug release was $90.88 \%$ respectively shown in Fig 7.

The in vitro drug release profile of tablets from formulation 2 batch was carried in phosphate buffer ( $\mathrm{pH}$ 6.8) for 15mts by using paddle type of device. From the in vitro dissolution data, F2 formulation was found that that drug release and cumulative \% of drug release was $88.3 \%$ respectively shown in Fig 8.

The in vitro drug release profile of tablets from formulation 3 batch was carried in phosphate buffer ( $\mathrm{pH}$ 6.8) for 15mts by using paddle type of device. From the in vitro dissolution data, F3 formulation was found that that drug release and cumulative \% of drug release was $83.81 \%$ respectively shown in Fig 9.

The in vitro drug release profile of tablets from formulation 4 batch was carried in phosphate buffer ( $\mathrm{pH}$ 6.8) for $15 \mathrm{mts}$ by using paddle type of device. From the in vitro dissolution data, F4 formulation was found that that drug release and cumulative \% of drug release was $92.78 \%$ respectively shown in Fig 10.

The in vitro drug release profile of tablets from formulation 5 batch was carried in phosphate buffer ( $\mathrm{pH}$ 6.8) for $15 \mathrm{mts}$ by using paddle type of device. From the in vitro dissolution data, F5 formulation was found that that drug release and cumulative \% of drug release was $88.73 \%$ respectively shown in Fig 11.

The in vitro drug release profile of tablets from each batch (F1 to F5) was carried in phosphate buffer ( $\mathrm{pH}$ 6.8) for $15 \mathrm{mts}$ by using paddle type of device. From the in vitro dissolution data, F1 formulation was found that that drug release is best and cumulative \% of drug release was $90.88 \%$ respectively, when compared to other formulations. shown in Fig 12.

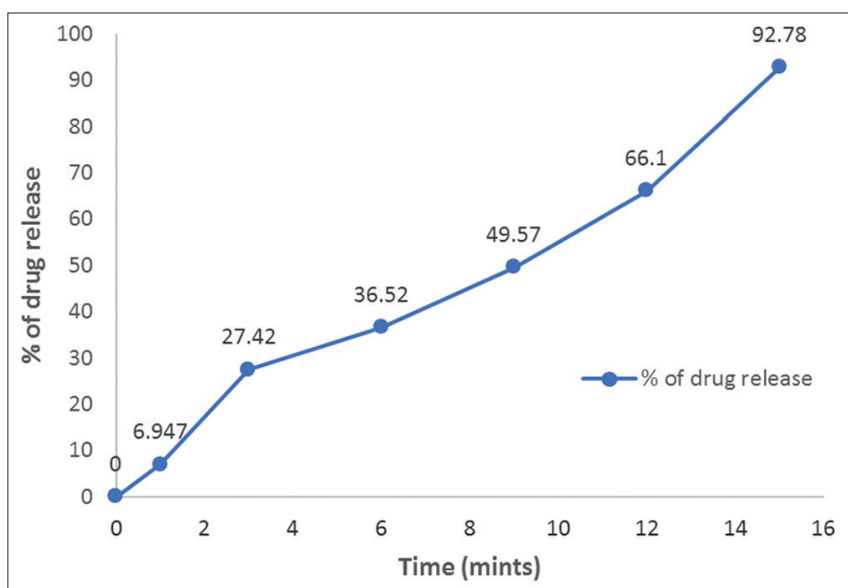

Fig. 10: Formulation-4 (F4)

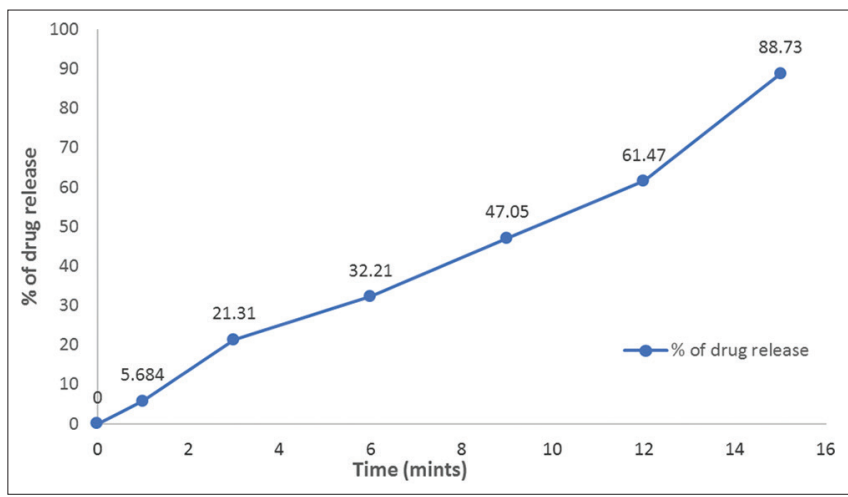

Fig. 11: Formulation-5 (F5)

\section{In vitro drug release study}

Tablets of all the formulations were subjected for in vitro release studies. The results are presented in Tables 9-14.

The present study was undertaken to formulate Ketorolac tromethamine oral dispersible tablet with three polymers namely sodium starch glycolate, cros carmellose sodium and in combination of three super disintegrants and by dry granulation technique. Before compression of the granules physical characters such as bulk density, tapped density, angle of repose, compressibility index and hausner ratio was determined and tabulated in Table 12.

\section{DISCUSSION}

Oral dispersible tablets of ketorolac tromethamine were prepared by direct compression method. Microscopic examination of tablets from each formulation batch showed circular result. 


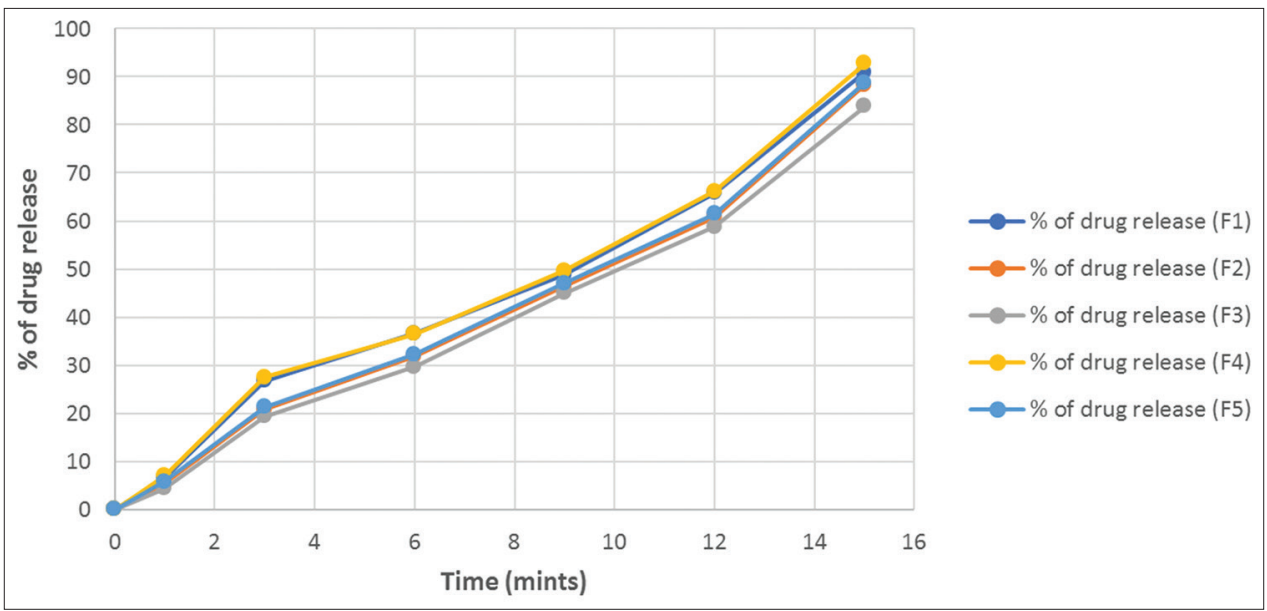

Fig. 12: Comparative dissolution study of different formulations with various ratios of super disintegrants

\section{CONCLUSION}

It has been observed from all formulations of pre compression and post compression studies were given with in the limits of values. The in vitro dissolution data, F1( combination of super disintegrant) formulation was found that the drug release is best and cumulative \% of drug release was $90.88 \%$ respectively, when compared to other formulation.

\section{REFERENCES}

1. Lorenzp-Lamosa ML, Cuna M, Vila-Jato JL, Torres D. Fast dissolving drug delivery system: An update. J Microencapsul 1997;14:607.

2. Habib W, Khankari R, Hontz J. Fast dissolving drug delivery system: Critical review in therapeutics. Drug Carrier Syst 2000;17:61-72.

3. Bradoo R, Shahani S, Poojary S, Deewan B, Sudarsan S. Fast dissolving drug delivery system. JAMA India 2001;4:27-31.
4. Dobetti L. Fast melting tablet: Development and technologies. Pharm Tech 2001;37:44-8.

5. Panigrahi D, Baghel S, Mishra B. Mouth dissolving tablets: A overview of preparation techniques, evaluation and patented technologies. J Pharm Res 2005;49:33-8.

6. Avani J, Amin F. Emerging trends in the development of orally disintegrating tablet technology - A review. Pharm Tech 2006;4:26-32.

7. Chaudhary PD, Chaudhary SP, Lanke SD, Nakul TK. Formulation and in vitro evaluation of taste masked orodispersible dosage forms of levocetrizine dihydrochloride. Indian J Pharm Educ Res 2007:41:319-27.

8. Kundu PK, Sahoo K. Recent trends in the developments of orally disintegrating tablet technology. Pharm Times 2008;40:11-5.

9. Sharma RS, Gupta GD. Formulation and characterization of fast dissolving tablets of promethazine theoclate. Asian J Pharm 2008; $16: 70-2$ 